\author{
Current Research in Agricultural Sciences \\ 2021 Vol. 8, No. 2, pp. 65-70. \\ $\operatorname{ISSN}(e): 2312-6418$ \\ $\operatorname{ISSN}(p): 2313-3716$ \\ DOI: $10.18488 /$ journal.68.2021.82.65.7O \\ (C) 2021 Conscientia Beam. All Rights Reserved. \\ check for \\ check for
updates
}

\title{
CONSTRUCTED WETLAND EFFLUENT IRRIGATION AS A POTENTIAL WATER AND NUTRIENT SOURCE FOR VEGETABLES
}

\author{
Okoye N. M \\ Department of Agricultural and Bioresources Engineering, Nnamdi Azikiwe \\ University Awka, Nigeria. \\ Email:nelsonokoye2003@yahoo.com Tel: +2348104068474
}

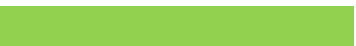

\begin{abstract}
A field study was conducted to evaluate the influence of constructed wetland effluent irrigation on the yield and productivity of Fluted Pumpkin (Telfairia occidentalis). The Telfairia occidentalis were planted in 12 beds ( 6 beds per treatment) measuring $1 \mathrm{~m}$ wide, $3 \mathrm{~m}$ long and $0.2 \mathrm{~m}$ high. The plants were grown for 8 weeks before they were harvested. The experimental plots were irrigated with secondary treated effluent from an experimental constructed wetland treating slaughterhouse wastewater. The control treatment involved the irrigation with tap water. The results show that the effluent used in the study was rich in nutrients and organic content. The result also revealed that the mean biomass yield of $146.14 \mathrm{~g}$, mean leaf length of $10.10 \mathrm{~cm}$, mean height of $97.50 \mathrm{~cm}$, mean leaf width of $5.36 \mathrm{~cm}$ and mean number of branches of 16.24 were significantly higher for the secondary treated slaughterhouse effluent irrigated plots compared to the values obtained for the control plots, indicating that effluent irrigation has a great potential to serve as not only a water source for vegetable cultivation, but also as a nutrient source for increased productivity.
\end{abstract}

Article History

Received: 15 February 2021 Revised: 19 March 2021 Accepted: 22 April 2021 Published: 25 May 2021

Keywords

Constructed wetland Irrigation

Slaughterhouse effluent

Telfairia occidentalis

Wastewater

Nutrient.

Contribution/Originality: This study is one of very few studies which have investigated the influence of secondary treated constructed wetland effluent irrigation on the yield and productivity of Telfairia occidentalis.

\section{INTRODUCTION}

A key component of water resource management is wastewater reuse. Reuse of wastewater from different sources can have a significant impact on water security [1]. Especially for a developing country like Nigeria, where water scarcity often leads to the utilization of water from questionable sources for both domestic and agricultural purposes. Carr, et al. [2] stated that $18 \%$ of the agricultural land is irrigated, of which $10 \%$ has been irrigated with reclaimed water. Water from non-conventional sources, such as treated wastewater that has undergone the necessary processes for the removal of pollutants, nutrients and pathogens, can play a vital role in augmenting agricultural water demands which is vital for achieving food security [3]. Reclaimed water can also be a solution for low rainfall periods [4]. Studies have also shown that irrigation with treated wastewater can be a good source of nutrients for soils of very low fertility [5,6]. Apart from serving as a cheap source of water and nutrients for plants, irrigation with treated wastewater can also reduce the problem of wastewater disposal. Utilization of wastewater for crop production can also reduce water pollution. A significant volume of water is used by the meat processing industry, leading to considerable large volumes of wastewater. Slaughterhouse wastewater is characterized by high organic load derived from different sources such as suspended particles of semi-digested and undigested feeds, blood etc. Irrigation of crops with raw wastewater has been associated with several serious risks 
including crop yields reduction, deterioration and contamination with pathogens [7]. However, these risks can be mitigated by using treated wastewater for crop irrigation, thereby reducing the pressure on fresh water resources. Constructed wetlands have been recommended for wastewater treatment, especially in developing countries where expensive and sensitive systems are not sustainable [8]. In general, constructed wetlands have been reported to achieve significant organic, nutrient and pathogen reduction [9-12] but effluents from constructed wetlands are still rich in plant nutrients. Therefore, studies evaluating the influence of wetland effluent irrigation on the performance of crops and soil properties are need of the hour in the context of wastewater reuse. The objective of the paper is to evaluate the influence of constructed wetland effluent irrigation on the productivity of Telfairia occidentalis.

\section{MATERIALS AND METHODS}

The field study was carried out on the grounds of the Agulu slaughterhouse. Agulu, which falls within the Awka Capital Territory, is one of the most populous towns in Anambra State, Nigeria. It lies within latitudes 6.04 ${ }^{\circ} \mathrm{N}$ and $6.09{ }^{\circ} \mathrm{N}$ and longitudes $7.00{ }^{\circ} \mathrm{E}$ and $7.03{ }^{\circ} \mathrm{E}$. Average annual rainfall in the area is $1923 \mathrm{~mm}$, with a maximum rainfall of $35.7^{\circ} \mathrm{C}$ in February and a minimum of $20.4^{\circ} \mathrm{C}$ in January. The study was carried out during the dry season (November to January) to minimize nutrient leaching due to rainwater. Effluent was collected from an experimental constructed wetland for secondary treatment of slaughterhouse effluent. A complete randomized design was employed for the study, with six replications. The Telfairia occidentalis were planted in 12 beds (6 beds per treatment) measuring $1 \mathrm{~m}$ wide, $3 \mathrm{~m}$ long and $0.2 \mathrm{~m}$ high, with a total of 15 plants per bed, as shown in Figure 1 . The soil in the experimental area was classified as sandy clay. The beds received about $2 \mathrm{~mm}$ of secondary treated effluent and tap water per day. The plants were harvested in January, after 8 weeks of planting and oven dried. The above ground dry biomass yield was the evaluated. Stem thickness, leaf length, leaf width, height and number of branches were also measured. The differences in the means of the two treatments were analyzed using one-way ANOVA with significant level set at $\mathrm{p}<0.05$. The physicochemical properties of the effluent and tap water were measured, while the influent and effluent organic (BOD) and nutrient $\left(\mathrm{NO}_{3}-\mathrm{N}\right)$ load of the constructed wetland were measured. For influent and effluent sampling, grab samples were collected using $500 \mathrm{ml}$ plastic containers washed in non-ionic detergent and rinsed with tap water prior to usage. The samples were immediately transported to the laboratory in an ice block filled cooler and stored in the refrigerator at about $4{ }^{\circ} \mathrm{C}$ prior to analysis. Biochemical oxygen demand (BOD), total suspended Solids (TSS), total dissolved solids (TDS) and ammonium nitrogen $\left(\mathrm{NH}_{4^{-}}\right.$ $\mathrm{N})$ were analyzed according to standard methods [13]. Nitrate nitrogen $\left(\mathrm{NO}_{3}-\mathrm{N}\right)$ and orthophosphate $\left(\mathrm{PO}_{4}{ }^{3-}\right)$ were analyzed using the US EPA approved general purpose field test kits by Hach Company [14].

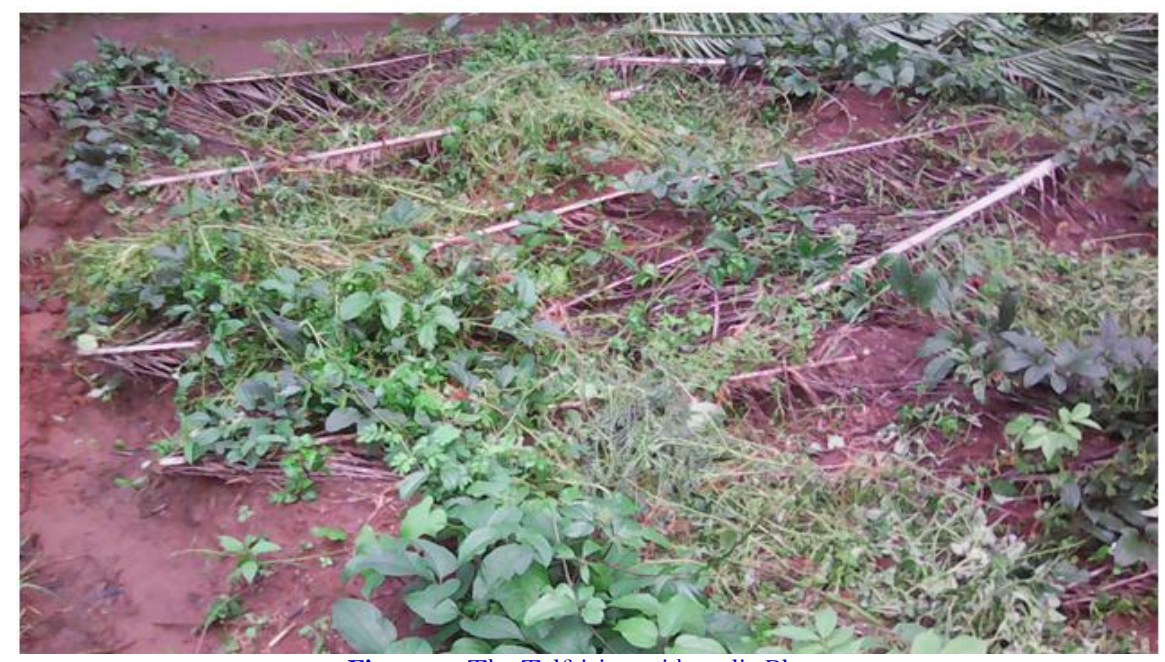

Figure-1. The Telfairia occidentalis Plots. 


\section{RESULT AND DISCUSSION}

\subsection{Wastewater Quality}

Figure 2 shows the measured influent and effluent organic and nutrient load of the constructed wetland. BOD and $\mathrm{NO}_{3}-\mathrm{N}$ contents were much higher in the influent, compared to the effluent, indicating a functional system.

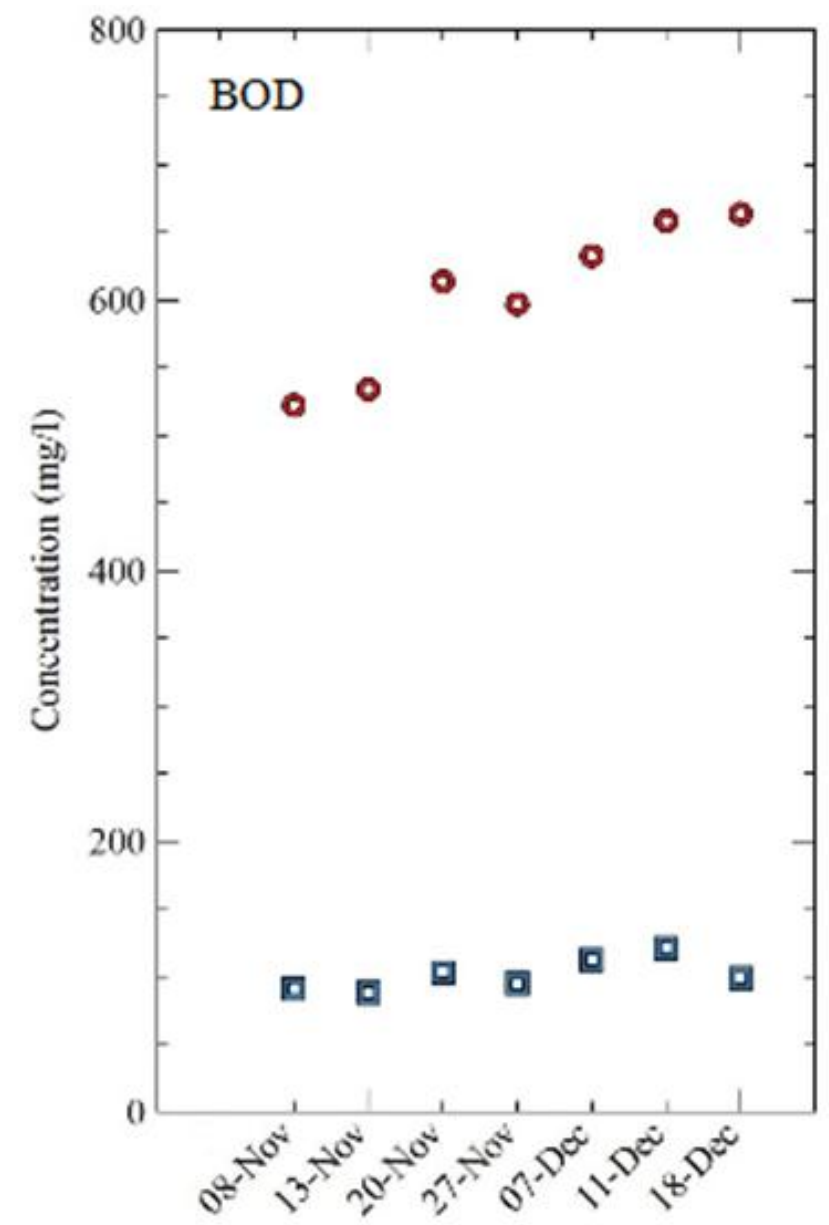

- Measured inlet

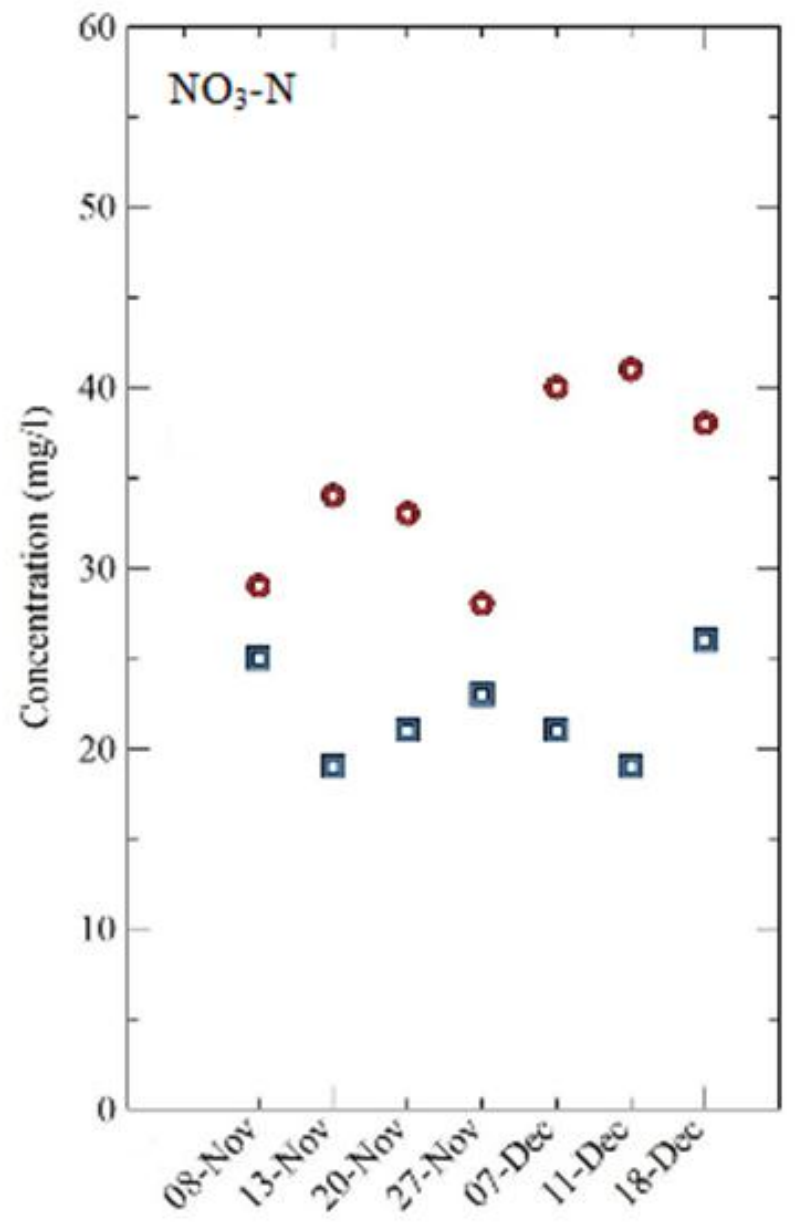

๑ Measured outlet

Figure-2. BOD and $\mathrm{NO}_{3}-\mathrm{N}$ concentrations measured at the inlet and outlet of the wetland.

Results of the physicochemical properties of the constructed wetland effluent and tap water used in the experiment are shown in Table 1. The results showed that all the determined physicochemical parameters were higher in the secondary-treated slaughterhouse effluent compared to the tap water. The effluent used in the study was rich in nutrients, particularly for nitrogen constituents, but was poor in phosphate. Also the organic content was also high.

Table-1. Effluent and tap water physicochemical properties.

\begin{tabular}{l|l|c|c}
\hline \multicolumn{3}{|c}{ Table-1. Effluent and tap water physicochemical properties. } \\
\hline S/No. & Parameter & Effluent & Tap Water \\
\hline 1 & pH & 7.53 & 7.91 \\
\hline 2 & Conductivity $(\mu \mathrm{S} / \mathrm{cm})$ & 1896 & 453 \\
\hline 3 & $\mathrm{BOD}(\mathrm{mg} / \mathrm{l})$ & 73.9 & 1.4 \\
\hline 4 & $\mathrm{TDS}(\mathrm{mg} / \mathrm{l})$ & 832.6 & 39.0 \\
\hline 5 & $\mathrm{TSS}(\mathrm{mg} / \mathrm{l})$ & 58.5 & 30.1 \\
\hline 6 & $\mathrm{NH}_{4}-\mathrm{N}(\mathrm{mg} / \mathrm{l})$ & 35.5 & 46.0 \\
\hline 7 & $\mathrm{NO}_{3}-\mathrm{N}(\mathrm{mg} / \mathrm{l})$ & 20.2 & 38.1 \\
\hline 8 & $\mathrm{PO}_{4}{ }^{3-}(\mathrm{mg} / \mathrm{l})$ & 5.8 & 1.5 \\
\hline
\end{tabular}


The values of the key physicochemical properties were within the set limits for long term use of reclaimed waters for irrigation as recommended by United States Environmetal Protection Agency (USEPA) [15]. However, the microbiological properties of slaughterhouse effluent have been reported to pose a high risk level for contamination and does not meet the quality requirements for irrigation, especially for crops eaten raw [16]. This is an indication that additional efforts is needed to minimize the risk of contamination, such as the use of drip irrigation system to provide the treated wastewater directly to the plant roots [17].

\subsection{Plant Productivity}

Results of the analysis of Telfairia occidentalis productivity for the effluent irrigated and control plots are shown in Table 2. The results of the mean above ground biomass yield (146.14g), mean leaf length (10.10cm), mean leaf width (5.36), mean height $(97.50 \mathrm{~cm})$ and mean number of branches (16.24) were found to be significantly higher $(\mathrm{p}<0.05)$ for effluent irrigated plots, compared to the control plot.

Table-2. Biomass yield of Fluted Pumpkin (Telfairia occidentalis) for the two treatments.

\begin{tabular}{l|l|c|c}
\hline \multirow{2}{*}{ S. No. } & \multirow{2}{*}{ Productivity Parameter } & \multicolumn{2}{|c}{ Treatment } \\
\cline { 3 - 4 } & & Effluent Irrigated & Control \\
\hline 1 & Biomass Yield $(\mathrm{g})$ & 146.14 & 82.04 \\
\hline 2 & Leaf length $(\mathrm{cm})$ & 10.10 & 3.92 \\
\hline 3 & Leaf width $(\mathrm{cm})$ & 5.36 & 2.58 \\
\hline 4 & Height $(\mathrm{cm})$ & 97.50 & 43.61 \\
\hline 5 & Number of branches & 16.24 & 9.66 \\
\hline
\end{tabular}

The significantly higher productivity recorded for plants irrigated with the secondary-treated constructed wetland effluent can be attributed to the manure content of the effluent compared to that of the tap water, as can be seen from the wastewater analysis. The high BOD of the wastewater contributed to the increased yield as BOD of wastewater has been reported to be an important criterion for judging the suitability of wastewater for irrigation [18]. Similar positive impact of wastewater irrigation on crop yield parameters was also reported [19]. Increased plant productivity was also observed as a result of the application of meat processing effluent, with increased nutrient loading [20]. Also secondary treated wastewater irrigation has been observed to stimulate fungal populations in the soil and enrich the antagonists of soil-borne pathogens [21]. However, lower yield of grains was reported for wheat crop irrigated with wastewater than the control, which was attributed to the presence of high concentration of heavy metals and dissolved salts in the wastewater [22] although it ran contrary to the findings by Mousavi, et al. [23] who reported that irrigation with treated wastewater had a significant positive impact on all characters of quality of maize.

\section{CONCLUSION}

The rational for this study was the fact that the country is experiencing a serious water challenge. So reuse of treated wastewater can help conserve scarce water resources. The results of the secondary treated constructed wetland effluent irrigation on the Telfairia occidentalis indicate a positive impact of the wastewater on plant yield. Reuse of treated wastewater enriched the soil with necessary nutrients that enable the plants to grow and flourish. However, efforts at not only maximizing the positive impact of effluent irrigation, but also minimizing any detrimental effects should be increased. While the results of wastewater reuse for irrigation are promising, further research is needed, especially on their long term effects on health and environment, before treated wastewater irrigation can be recommended as an alternative to fresh water irrigation.

Funding: This study received no specific financial support.

Competing Interests: The authors declare that they have no competing interests.

Acknowledgement: All authors contributed equally to the conception and design of the study. 


\section{REFERENCES}

[1] C. Grant, "Influence of phosphate fertilizer on Cadmium in agricultural soils and crops," Pedologist, vol. 56, pp. 143155, 2011.

[2] R. Carr, U. Blumenthal, and D. Mara, Health guidelines for the use of wastewater in agriculture: developing realistic guidelines, in: C. Scott, N. I. Faruqui and L. Raschid-Sally (eds.) Wastewater use in irrigated agriculture: confronting the livelihood and environmental realities, Commonwealth Agricultural Bureau International. Canada: Orient-Longman,and IDRC, Ottawa, 2004.

[3] M. Qadir, B. R. Sharma, A. Bruggeman, R. Choukr-Allah, and F. Karajeh, "Non-conventional water resources and opportunities for water augmentation to achieve food security in water scarce countries," Agricultural Water Management, vol. 87, pp. 2-22, 2007.Available at: https://doi.org/10.1016/j.agwat.2006.03.018.

[4] F. Monnet, N. Vaillant, A. Hitmi, P. Vernay, A. Coudret, and H. Sallanon, "Treatment of domestic wastewater using the nutrient film technique (NFT) to produce horticultural roses," Water Research, vol. 36, pp. 3489-3496, 2002.Available at: https://doi.org/10.1016/s0043-1354(02)00058-1.

[5] D. J. Reuter and J. B. Robinson, Plant analysis: An interpretation manual. Melbourne: CSIRO Publishing, 1997.

[6] F. Rivera, A. Warren, C. R. Curds, E. Robles, A. Gutierrez, E. Gallegos, and A. Calderón, "The application of the root zone method for the treatment and reuse of high-strength abattoir waste in Mexico," Water Science and Technology, vol. 35, pp. 271-278, 1997.Available at: https://doi.org/10.2166/wst.1997.0215.

[7] J. Zavadil, "The effect of municipal wastewater irrigation on the yield and quality of vegetables and crops," Soil and Water Research, vol. 4, pp. 91-103, 2009.Available at: https://doi.org/10.1722 1/40/2008-swr.

[8] N. M. Okoye, C. N. Madubuike, I. U. Nwuba, and L. C. Orakwe, "Growth and treatment performance of three macrophytes in a pilot-scale horizontal subsurface flow constructed wetland for slaughterhouse wastewater," Archives of Current Research International, vol. 14, pp. 1-7, 2018.Available at: https://doi.org/10.9734/acri/2018/39333.

[9] A. E. Adeniran, A. Aina, and O. Oshunrinade, "Performance characteristics of pollutants along the longitudinal profile of a subsurface flow constructed wetland for domestic sewage treatment in the University of Lagos, Nigeria," Journal of Water Resource and Protection, vol. 6, pp. 104-1 13, 2014.Available at: https://doi.org/10.4236/jwarp.2014.62015.

[10] J. P. Mairi, T. Lyimo, and K. Njau, "Performance of subsurface flow constructed wetland for domestic wastewater treatment," Tanzania Journal of Science, vol. 38, pp. 53-64, 2012.

[11] J.-j. Chang, S.-q. Wu, Y.-r. Dai, W. Liang, and Z.-b. Wu, "Treatment performance of integrated vertical-flow constructed wetland plots for domestic wastewater," Ecological Engineering, vol. 44, pp. 152-159, 2012.Available at: https://doi.org/10.1016/j.ecoleng.2012.03.019.

[12] M. Chen, Y. Tang, X. Li, and Z. Yu, "Study of heavy metals removal efficiencies of constructed wetlands with different substrates," Journal of Water Resource and Protection, vol. 1, pp. 22-28, 2009.Available at: https://doi.org/10.4236/jwarp.2009.11004.

[13] American Public Health Association (APHA), Standard methods for the examination of water and wastewater, 20 th ed. Washington DC, USA: American Public Health Association, American Water Works Association and Water Environment Federation, 1998.

[14] United States Environmetal Protection Agency (USEPA), "Approved general-purpose methods |CWAMethods|US EPA, 2016. Retrieved from http://water.epa.gov/cwa-methods," 2016.

[15] United States Environmetal Protection Agency (USEPA), Guidelines for water reuse. EPA/625/R-04/108. Washington, DC: U.S. Environmental Agency and U.S. Agency for International Development, 2004.

[16] WHO, "Guidelines for the safe use of wastewater, excreta and greywater: Wastewater use in agriculture." vol. 2, ed Geneva, Switzerland: WHO Press, 2006.

[17] C. A. De Freitas, A. R. da Silva, F. M. Bezerra, R. R. d. Andrade, F. S. Mota, and B. F. d. Aquino, "Growth of irrigated sunflower under different water sources and nitrogen fertilization," Brazilian Journal of Agricultural and Environmental Engineering, vol. 16, pp. 1031-1039, 2012. 
[18] V. Nashikkar, "Effect of reuse of high-bod wastewaters for crop irrigation on soil nitrification," Environment International, vol. 19, pp. 63-69, 1993.Available at: https://doi.org/10.1016/0160-4120(93)90007-5.

[19] R. R. Warrier and S. Saroja, "Impact of depolluted electroplating effluents on the growth and productivity of selected crops," Ecology and Environment Construction, vol. 6, pp. 251-253, 2000.

[20] J. Luo, S. Lindsey, and J. Xue, "Irrigation of meat processing wastewater onto land," Agriculture, Ecosystems $\mathcal{E}^{\circ}$ Environment, vol. 103, pp. 123-148, 2004.Available at: https://doi.org/10.1016/j.agee.2003.10.008.

[21] G. Disciglio, G. Gatta, A. Libutti, A. Gagliardi, A. Carlucci, F. Lops, F. Cibelli, and A. Tarantino, "Effects of irrigation with treated agro-industrial wastewater on soil chemical characteristics and fungal populations during processing tomato crop cycle," Journal of Soil Science and Plant Nutrition, vol. 15, pp. 765-780, 2015.

[22] K. Swaminathan, K. Manonmani, and B. Sarojini, "Studies on the toxicity of South India viscose factory effluent on ground nut(Arachis hypogea)," Journal of Environmental Biology, vol. 13, pp. 253-260, 1992.

[23] S. R. Mousavi, M. Galavi, and H. Eskandari, "Effects of treated municipal wastewater on fluctuation trend of leaf area index and quality of maize (Zea mays)," Water Science and Technology, vol. 67, pp. 797-802, 2013.Available at: https://doi.org/10.2166/wst.2012.624. 